(Vol.VI, Maret 2015 )

\title{
Hubungan Anemia dengan Kejadian Dismenorrhoe di Prodi. DIII Kebidanan Adi Buana Surabaya.
}

\author{
Damarati Azaria \\ Tenaga Pengajar Prodi DIII Kebidanan, Universitas PGRI Adi Buana Surabaya
}

\section{ABSTRAK}

Anemia di indonesia pada remaja putri dari hasil SKRT tahun 2000 didapatkan sebanyak 6,3 juta orang $(57,1 \%)$. Berbagai masalah bisa ditimbulkan oleh keadaan anemia, salah satunya adalah Dismenorrhoe yang bisa mengganggu aktivitas seseorang. Tujuan dari penelitian ini adalah untuk mengetahui hubungan Anemia dengan kejadian Dismenorrhoe di Prodi DIII Kebidanan Adi buana Surabaya.

Dalam penelitian ini digunakan metode Analitik korelasi dengan desain penelitian cross sectional yang dilakukan pada bulan oktober 2014. Populasi penelitian ini adalah semua mahasiswa Prodi DIII Kebidanan Adi buana sebanyak 176 orang. Sampel penelitian adalah sebagian dari mahasiswa yang berjumlah 46 orang mahasiswa semester 4. Analisis data yng digunakan adalah analisis statistik Chi quadrat.

Berdasarkan hasil penelitian diperoleh mahasiswa sebanyak 46 orang yang mengalami Anemia 22 orang (48,82\%), yang mengalami dismenorrhoe sebanyak 27 orang $(58,70 \%)$. Berdasarkan uji Chi quadrat didapatkan $X^{2}$ hitung $=1,045$ lebih kecil dari $X^{2}$ tabel $=3,841$. Sehingga $\mathrm{HO}$ diterima yang berarti tidak ada hubungan Anemia dengan kejadian dismenorrhoe.

Saran dari peneliti adalah dilakukan penelitian lanjutan untuk mengetahui berbagai faktor yang ada kaitannya dengan kondisi Anemia.

Kata kunci : Anemia, Dismenorrhoe

\section{PENDAHULUAN}

Anemia adalah suatu keadaan dimana kadar haemoglobin dalam darah kurang dari kondisi normal. Menurut World Health Organization (WHO,1997) batas kadar $\mathrm{Hb}$ remaja putri untuk diagnosis Anemia apabila kadar Haemoglobin kurang dari 12 $\mathrm{gr} / \mathrm{dl}$. Sedangkan di Indonesia kriteria Anemia di klinik (dirumah sakit atau praktek klinik) yang termasuk kriteria Anemia adalah kadar Haemoglobin kurang dari $10 \mathrm{gr} / \mathrm{dl}$. Secara tepat, Anemia adalah suatu keadaan dimana terjadi penurunan terhadap massa sel darah merah. Berbagai faktor yang bisa menyebabkan terjadinya Anemia, diantaranya adalah kurang asupan gizi terutama asupan zat besi, perdarahan menahun, gangguan absorbsi besi dan masih banyak lagi.

Berdasarkan survey yang
dilakukan oleh WHO tahun 2001 yang
dikutip Usman (2008), didapatkan di
Amerika Serikat 30-40\% balita dan
wanita usia subur (WUS) mengalami
status Anemia defisiensi besi.
Sedangkan hasil survei kesehatan
rumah tangga (SKRT) pada tahun 2001
dalam Dahuri (2005) oleh Dinas
Kesehatan Kabupaten Tangerang
didapatkan $26,5 \%$ anak usia sekolah
dan remaja mengalami Anemia gizi
besi. Menurut soedjatmiko (2000)
dalam Rachmawati (2007) angka
kejadian Anemia pada remaja putri
sebesar 6,3 juta jiwa ( $57,1 \%$ ).
Berbagai masalah yang bisa
disebabkan oleh keadaan Anemia,
salah satunya adalah terjadinya
Dismenorrhoe, yang bisa mengganggu
aktifitas bahkan sampai memerlukan
istirahat ditempat tidur, sehingga


menganggu pula kegiatan belajar pada anak remaja. Dismenrrhoe adalah rasa sakit saat menstruasi sampai dapat mengganggu aktifitas sehari-hari (Manuaba, 2001).

Di Prodi DIII Kebidanan Unipa dimana mahasiswanya adalah perempuan semua yang rata-rata usianya antara 19 th sampai 22 th hampir setiap bulan ada mahasiswa yang mengalami kejadian Dismenorrhoe sehingga harus ijin untuk tidak bisa mengikuti kuliah. Hal ini sangat mengganggu pencapaian hasil proses belajar, sehingga perlu dilakukan penelitian adakah hubungan antara keadaan Anemia dengan kejadian Dismenorhoe pada mahasiswa Prodi DIII Kebidanan Unipa Surabaya.

\section{RUMUSAN MASALAH}

Adakah hubungan Anemia dengan kejadian Dismenorrhoe pada mahasiswa semester IV di Prodi DIII Kebidanan UNIPA Surabaya?

\section{TUJUAN PENELITIAN}

1. Mengidentifikasi Haemoglobin yang rendah (Anemia) pada mahasiswa semester IV Prodi DIII Kebidanan UNIPA Surabaya.

2. Mengidentifikasi

kejadian

Dismenorrhoe pada mahasiswa semester IV Prodi DIII Kebidanan UNIPA Surabaya.

3. Menganalisis hubungan kadar Haemoglobin rendah (Anemia) dengan kejadian Dismenorrhoe pada mahasiswa semester IV Prodi DIII Kebidanan UNIPA Surabaya.

\section{METODE PENELITIAN Desain Penelitian}

Penelitian ini merupakan penelitian Analitik dengan pendekatan yang bersifat Cross Sectional.

\section{Populasi dan Sampel}

Populasi dalam penelitian ini adalah semua Mahasiswa Prodi D-III Kebidanan UNIPA sejumlah 176 mahasiswa. Sampel yang digunakan dalam penelitian ini adalah mahasiswa semester IV sebanyak 46 mahasiswa.

\section{HASIL PENELITIAN \\ Data Umum}

Pada bagian ini akan disajikan tentang gambaran umum tempat penelitian, data umum yang terdiri dari karakteristik responden berdasarkan usia, saat pertama kali haid atau usia menarche.

\section{Gambaran umum tempat penelitian \\ Prodi DIII Kebidanan Adi Buana} adalah satu satunya prodi dibidang kesehatan Yang dimiliki oleh Universitas Adi Buana Surabaya, yang berdiri sejak th 2004, terletak di komplek kampus Adi Buana Menanggal. Mahasiswa yang menempuh pendidkan di Prodi DIII Kebidanan Adi buana berasal dari berbagai daerah baik disekitar Surabaya maupun dari luar kota bahkan luar pulau diantaranya, Bawean, Kangean, Kalimantan, Flores, Sumbawa, NTT, dan Papua.

Jumlah mahasiswa setiap angkatan bervariasi antara 50 sampai 80 mahasiswa. Batasan usia mahasiswa pada saat masuk Prodi DIII Kebidanan Adi Buana minimal 18 tahun sedangkan batas maksimal 35 tahun. Namun ada juga yang lebih dari usia 35 tahun karena tugas belajar dari institusi Kesehatan.

Dosen tetap yang mengajar di Prodi kebidanan ada 10 orang. Dari berbagai daerah asal mahasiswa maka kodisi status kesehatan dan kebiasaan para mahasiswa dalam memenuhi kebutuhan nutrisi juga berbeda sehingga perlu dilakukan pengkajian tentang status kesehatannya, teutama masalah kadar haemoglobinnya yang bisa dipakai sebagai salah satu indikator status kesehatan wanita. 


\section{Karakteristik Responden}

\section{Berdasarkan Usia}

Tabel 1 Distribusi frekuensi usia mahasiswa Prodi Kebidanan Adi Buana Surabaya tahun 2014

\begin{tabular}{lcc}
\hline USIA & $\Sigma$ & $\%$ \\
\hline$<20$ th & 4 & 8,7 \\
$20-25$ th & 39 & 84,8 \\
$26-30$ th & 2 & 4,3 \\
$>30$ th & 1 & 2,2 \\
\hline \multicolumn{1}{r}{ TOTAL } & $\mathbf{4 6}$ & $\mathbf{1 0 0}$ \\
\hline
\end{tabular}

Dari tabel 1 menunjukkan bahwa terbanyak usia mahasiswa Prodi D3 Kebidanan Adi Buana adalah usia 20 25 tahun yaitu 39 orang $(84,8 \%)$.

Tabel 2 Distribusi frekuensi usia menarche pada mahasiswa Prodi Kebidanan Adi Buana

\begin{tabular}{lcc}
\hline USIA & $\boldsymbol{\Sigma}$ & $\%$ \\
\hline$<12$ th & 6 & 1,3 \\
$12-15$ th & 39 & 84,8 \\
$>15$ th & 1 & 2,2 \\
\hline TOTAL & $\mathbf{4 6}$ & $\mathbf{1 0 0}$ \\
\hline
\end{tabular}

Dari Tabel 2 menunjukkan bahwa dari 46 responden terbanyak menarche dialami pada usia 12 - 15 tahun ( 39 orang) atau $84,8 \%$.

\section{Data Khusus}

Pada sub bab ini akan disajikan data yang meliputi hasil pemeriksaan kadar haemoglobin pada responden apakah masuk kategori anemia atau tidak anemia, dan data tentang kejadian dysmenorrhoe yang dialami oleh responden.
Distribusi frekuensi hasil pemeriksaan kadar $\mathrm{Hb}$ (status kesehatan) mahásiswa Prodi Kebidanan Adi Buana Surabaya tahun 2014

\begin{tabular}{lcccccl}
\hline & ANEMIA & \multicolumn{2}{c}{ TIDAK } & \multicolumn{1}{c}{ TOTAL } \\
ANEMIA
\end{tabular}

Tabel 4 Distribusi frekuensi kejadian dysmenorhoe pada mahasiswa Prodi Kebidanan Adi Buana Surabaya tahun 2014

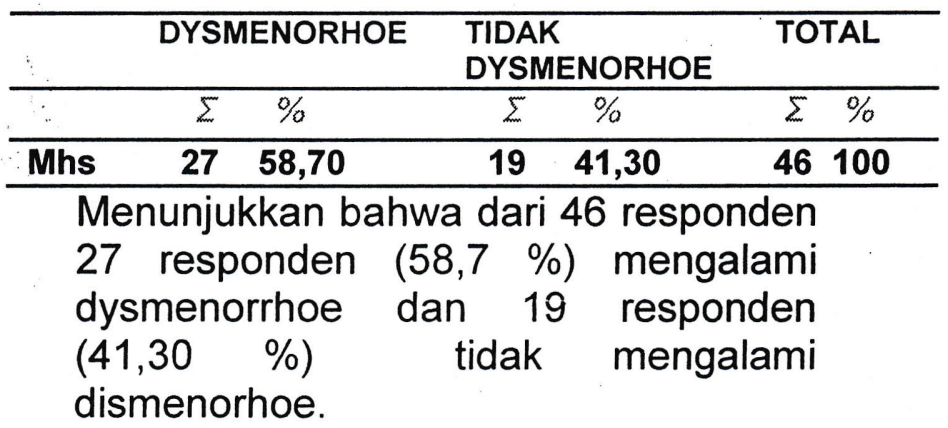

Tabel 5 tabulasi silang hubungan anemia dengan kejadian dismenorhea pada mahasiswa Prodi Kebidanan Adi Buana Surabaya tahun 2014

\begin{tabular}{|c|c|c|c|}
\hline $\begin{array}{l}\text { STATUS } \\
\text { KES. }\end{array}$ & DYSMENORHOE & $\begin{array}{l}\text { TIDAK } \\
\text { DYSMENORHOE }\end{array}$ & TOTAL \\
\hline Anemin & $\sum_{12} \%$ & $\sum_{10} \%$ & $\begin{array}{ll}\sum & \% \\
22 & 100\end{array}$ \\
\hline $\begin{array}{l}\text { Tidak } \\
\text { Anemia }\end{array}$ & 1562,5 & 937,5 & 24100 \\
\hline Total & 2758,7 & $19 \quad 41,3$ & 46100 \\
\hline
\end{tabular}

Berdasarkan tabel 5 dari hasil tabulasi silang antara anemia dan kejadian dysmenorhoe dari 46 responden , 24 responden yang tidak anemia 15 orang $(62,5 \%)$ mengalami dismenorhoe. Dan 22 responden yang anemia, 12 $(54,5 \%)$ mengalami dismenorhoe.

Hasil analisa data 
Hasil perhitungan manual Chi Kuadrat (Hubungan Anemia dengan Kejadian Dismenorhea)

\begin{tabular}{|l|cr|rr|c|}
\hline & \multicolumn{2}{|l|}{ Dismenorhea } & \multicolumn{2}{l|}{$\begin{array}{l}\text { Tidak } \\
\text { Dismenorhea }\end{array}$} & Total \\
\hline Anemia & 12 & 12,91 & 10 & 9,09 & 22 \\
\hline $\begin{array}{l}\text { Tidak } \\
\text { Anemia }\end{array}$ & 15 & 14,08 & 9 & 9,91 & 24 \\
\hline Total & \multicolumn{2}{|l|}{27} & & 19 & 46 \\
\hline
\end{tabular}

Rumus Chi Kuadrat $=X^{2}=\Sigma($ fo $-\mathrm{fc})$

$$
\begin{aligned}
\mathbf{F} \mathbf{c} & =\frac{(12-12,91)^{2}}{12,91}+\frac{(10-9,09)^{2}}{9,09}+\frac{(15-14,08)^{2}}{14,08}+\frac{(9-9,91)^{2}}{9,91} \\
& =0,064+0,091+0,83=1,045
\end{aligned}
$$

Dengan $\mathrm{df}=1$ dan $\alpha=0,05$ maka di peroleh $X^{2}$ hitung $=1,045$ dan $X^{2}$ tabel $=$ 3,841 , karena $X^{2}$ hitung $<X^{2}$ tabel maka Ho diterima berarti dapat disimpulkan bahwa tidak ada hubungan antara anemia dengan kejadian dismenorhea.

\section{PEMBAHASAN}

Analisis hubungan antara Anemia dengan kejadian dismenorrhoe di Prodi D3 Kebidanan Adi Buana

Berdasarkan tabel 5.2.3

menunjukkan bahwa dari 24 mahasiswa yang tidak Anemia sebanyak 15 orang $(62,5 \%)$ mengalami dismenorrhoe dan 9 orang $(37,5 \%)$ tidak mengalami dismenorrhoe. Sedangkan dari 22 mahasiswa yang Anemia sebanyak 12 orang $((54,5 \%) \quad$ mengalami dismenrrhoe.

Berdasarkan uji statistik dengan menggunakan uji Chi Quadrad didapatkan hasil : Dengan $\mathrm{df}=1$ dan $\alpha$ $=0,05$ maka di peroleh $X^{2}$ hitung $=$ 1,045 dan $X^{2}$ tabel $=3,841$, karena $X^{2}$ hitung $<X^{2}$ tabel maka Ho diterima berarti dapat disimpulkan bahwa tidak ada hubungan antara anemia dengan kejadian dismenorhea.

Kejadian Dismenorrhoe salah satu penyebabnya adalah faktor konstitusi (Wignyosastro,2007) diantaranya adalah kondisi Anemia yaitu keadaan defisiensi eritrosit atau haemoglobin sehingga menyebabkan kemampuan mengangkut oksigen berkurang dan dapat menyebabkan gangguan atau hambatan pada pertumbuhan sel otak dan dapat menurunkan daya tahan tubuh seseorang, termasuk daya tahan tubuh terhadap rasa nyeri.

Faktor penyebab terjadinya dismenorrhoe bukan hanya karena keadaan Anemia tetapi juga faktorfaktor lain diantaranya adalah faktor kejiwaan, seperti adanya ketidaksiapan remaja putri dalam menghadapi perkembangan dan pertumbuhan pada dirinya sehingga menyebabkan gangguan psikis yang akhirnya menyebabkan gangguan fisiknya misalnya gangguan nyeri saat haid. Wanita memiliki emosional yang tidak stabil, sehingga mudah mengalami dismenorrhoe. Faktor lain yang bisa mempengaruhi kejadian dismenorrhor adalah faktor resiko. Yang termasuk dalam faktor resiko adalah Menarche pada usia lebih awal, belum pernah hamil, lama menstruasi lebih dari 7 hari, umur. Dari 46 mahasiswa yang diteliti usia menarche yang lebih dini terdapat 6 orang, dan rata-rata usia dari mahasiswa terbanyak adalah 20 th sampai 25 th yang merupakan usia produktif. Untuk mengetahui faktor yang dominan sebagai penyebab dari kejadian dismenorrhoe perlu dilakukan penelitian tentang faktor-faktor lain selain dari kondisi Anemia.

Dari sebanyak 46 mahasiswa terdapat 47,82 mengalami Anemia, hal ini merupakan jumlah yang cukup besar sehingga menunjukkan bahwa kondisi status kesehatan dari sebagian mahasiswa kurang baik, oleh sebab itu perlu adanya penelitian lebih lanjut untuk mengkaji bagaimana asupan nutrisi dari mahasiswa yang melalui asupan nutrisi yang seimbang akan menghasilkan kader bangsa yang sehat, mengingat mahasiswa adalah calon penerus yang akan menentukan bagaimana bangsa ini kedepan. 
SIMPULAN DAN SARAN

\section{Simpulan}

Berdasarkan hasil penelitian dan hasil analisis dari penelitian yang berjudul "Hubungan Anemia dengan kejadian Dismenorrhoe " maka dapat disimpulkan : Tidak ada hubungan antara anemia dengan kejadian dismenorhea di Prodi DIII Kebidanan Adi Buana Surabaya.

\section{Saran}

Berdasarkan hasil penelitian maka saran yang diberikan adalah : Perlu dilakukan penelitian lanjutan tentang pola makan dan kejadian anemia \& Perlu penelitian tentang hubungan kejadian anemia dengan prestasi belajar.

\section{DAFTAR PUSTAKA}

Alimul, Azis. (2007). Metode Penelitian Kebidanan \& Tehnik Analisa Data.Jakarta:SalembaMedika

Arisman. (2010). Gizi dalam Daur Kehidupan. Jakarta : EGC

Arikunto, S. 2002. Prosedur Penelitian. Jakarta : Rineka Cipta

Bakta, I Made. (2006). Hematologi Klinik Ringkas. Jakarta : EGC

Budiono. 2004. Konsep Dasar Status Gizi. Jakarta : EGC

Manuaba. 1998. IImu Kebidanan Penyakit Kandungan dan Keluarga Berencana Untuk Pendidikan Bidan. Jakarta : EGC

Mochtar, R. 1998. Sinopsis Obstetri Jilid I. Jakarta : EGC

Notoatmodjo. (2010). Metodologi Penelitian Kesehatan. Jakarta : Rineka Cipta

Nursalam. (2007). Konsep dan Penerapan Metodologi Penelitian
IImu Keperawatan. Jakarta: Salemba M

Prawirohardjo, S. 2001. Buku Acuan Nasional Maternal dan Neonatal. Jakarta : Bina Pustaka

Saifuddin, Bani Abdul. (2002). Buku Acuan Nasional Pelayanan Kesehatan Maternal Neonatal. Jakarta, YBP - SP

Sugiyono,(2011).Metode Penelitian Kuantitatif Kualitatif dan R\&G. Bandung: Alphabeta

Suharsini, Arikunto. (2010). Prosedur Penelitian Suatu Pendekatan Praktik. Rineke Cipta. Jakarta.

Sulistyawati, (2009). Asuhan Kebidanan pada Masa Kehamilan. Salemba Madika: Jakarta

Supariasa. (2002). Penilaian Status Gizi. Jakarta : EGC

Wiknjosastro, Hanifa. (2005). IImu Kebidanan. Jakarta : Yayasan Bina

Pustaka 